\title{
Combined use of phenoxybenzamine and dopamine for low cardiac output syndrome in children at withdrawal from cardiopulmonary bypass
}

\author{
MITSUO KAWAMURA, OSAMU MINAMIKAWA, HIROSHI YOKOCHI, \\ SHIGEO MAKI, TAKASHI YASUDA, YUTAKA MIZUKAWA
}

From the Department of Cardiovascular Surgery, Meijyo Hospital, Nagoya, fapan

SUMMARY The combined use of phenoxybenzamine and dopamine was applied in infants and children when it was difficult to come off cardiopulmonary bypass for low cardiac output. The rationale of this method is to prevent the alpha-adrenergic action of dopamine by phenoxybenzamine and to encourage the beta-adrenergic and direct specific action of dopamine. Dopamine was used in dosage of 10 to $30 \mu \mathrm{g} / \mathrm{kg}$ per min after the additional administration of a half of the initial dosage of phenoxybenzamine; this was infused by drip always in a dosage of 0.5 to $1.0 \mathrm{mg} / \mathrm{kg}$ during the first half of cardiopulmonary bypass.

It was possible to come off cardiopulmonary bypass with a stable haemodynamic state (mean arterial pressure more than $60 \mathrm{mmHg}$ and total peripheral vascular resistance less than 2000 dynes s cm${ }^{-5}$ ) and a good urinary output.

Dopamine is a biochemical precursor of norepinephrine which increases myocardial contractile force by a beta-adrenergic action and produces mild vasoconstriction by an alpha-adrenergic action. ${ }^{1}$ It also produces renal and mesenteric vasodilatation by a direct specific action, not antagonised by either alpha- or beta-adrenergic blocking agents. ${ }^{23}$ This unique combination of properties provides a rational basis for the use of dopamine in the treatment of cardiogenic shock.

The combined use of dopamine and phenoxybenzamine, an alpha-adrenergic blocking agent, ${ }^{45}$ was attempted in the treatment of low cardiac output syndrome in patients coming off cardiopulmonary bypass.

\section{Subjects and methods}

Studies were made on 27 patients (age range 8 months to 6 years and 8 months) with congenital heart disease, who underwent open-heart surgery at Meijyo Hospital from July 1977 to June 1978 (Table 1). The combined use of phenoxybenzamine and dopamine was attempted in nine patients where difficulty had occurred in attempting to come off cardiopulmonary bypass. The other 18 patients, in whom phenoxybenzamine only was used, were studied as controls (Table 2).

Received for publication 2 July 1979
Cardiopulmonary bypass was accomplished with a small roller pump arranged for paediatric perfusion and a Temptrol oxygenator designed for infants. The haemodilution ratio was 35 to 45 per cent using the normothermic method and 20 to 35 per cent using the hypothermic method. The perfusion flow was checked and controlled every 15 minutes during cardiopulmonary bypass in order to maintain optimum perfusion. ${ }^{6}$ It resulted in a perfusion index of 3.4 to $3.91 / \mathrm{m}^{2}$ per min at 15 minutes of bypass at which time the haemoglobin concentration showed the minimum value. Total circulatory arrest within 30 minutes was applied when the oesophageal temperature was $20^{\circ} \mathrm{C}$ (Table 2). The practice of administration of phenoxybenzamine and dopamine is as follows. Phenoxybenzamine was infused by drip into an oxygenator at a dosage of 0.5 to $1.0 \mathrm{mg} / \mathrm{kg}$ within the first half of cardiopulmonary bypass in all cases of this series. Whenever dopamine was necessary in the cases in which it was difficult to come off cardiopulmonary bypass, dopamine 10 to $30 \mu \mathrm{g} / \mathrm{kg}$ per min was given after the additional administration of half the initial dose of phenoxybenzamine and was gradually reduced.

Arterial pressure (AP), central venous pressure (CVP), perfusion flow, urinary output, body temperature, electrocardiogram, and electroencephalogram were monitored continuously. Blood gas analysis, acid-base status, electrolyte balance, 
haemoglobin, and free haemoglobin values were measured at 15-minute intervals during cardiopulmonary bypass. The perfusion index (PI) and total peripheral vascular resistance (TPVR) were calculated using the following formula:

PI $\left(1 / \mathrm{m}^{2}\right.$ per $\left.\mathrm{min}\right)=$ perfusion flow litres per minute per square metre of surface area

$$
\begin{aligned}
& \text { TPVR (dynes } \mathrm{s} \mathrm{cm}^{-5} \text { ) }= \\
& \frac{[\overline{\mathrm{AP}}-\overline{\mathrm{CVP}}(\mathrm{mmHg})] \times 1332^{\star} \times 60}{\text { Perfusion flow }(\mathrm{ml} / \mathrm{min})}
\end{aligned}
$$

$\star 1332$ is the factor to convert $\mathrm{mmHg}$ to dynes $/ \mathrm{cm}^{2}$. Results are expressed as mean \pm SD.

\section{Results}

NORMOTHERMIC GROUP

Arterial oxygen tension was $238 \pm 51 \mathrm{mmHg}$ and carbon dioxide tension was $40 \pm 8 \mathrm{mmHg}$. Arterio-

\begin{tabular}{|c|c|c|c|c|}
\hline & \multicolumn{2}{|c|}{ Normothermia } & \multicolumn{2}{|c|}{ Hypothermia } \\
\hline & $P O B$ & $P O B+D A$ & $P O B$ & $P O B+D A$ \\
\hline \multirow{6}{*}{$\begin{array}{l}\text { TOF } \\
\text { +PDA } \\
\text { VSD } \\
\text { + PDA } \\
\text { + ASD } \\
\text { + ASD + PS } \\
\text { + PS + AR } \\
\text { + MR } \\
\text { + TCRV }\end{array}$} & 3 & 4 & $1^{\star}$ & \\
\hline & 6 & 2 & 1 & \\
\hline & 1 & & & 1 \\
\hline & 1 & & & \\
\hline & 1 & & & 1 \\
\hline & 1 & & & \\
\hline ECD & & & & \\
\hline $\begin{array}{l}\text { +ASD } \\
+ \text { ASD + PS }\end{array}$ & & & 1 & \\
\hline$+M R$ & 1 & 1 & & \\
\hline Total & 14 & 7 & 4 & 2 \\
\hline
\end{tabular}

Table 1 Patient population

POB, phenoxybenzamine; DA, dopamine; TOF, tetralogy of Fallot; PDA, persistent ductus arteriosus; VSD, ventricular septal defect; ASD, atrial septal defect; PS, pulmonary stenosis;

AR, aortic regurgitation; MR, mitral regurgitation; TCRV, twochambered right ventricle; ECD, endocardial cushion defect.

$\star$ After Blalock's operation. venous difference in oxygen saturation was from 30 to 40 per cent and $\mathrm{pH}$ value in arterial and venous blood was $7 \cdot 4 \pm 0.05$ during cardiopulmonary bypass. Mean arterial pressure was maintained above $60 \mathrm{mmHg}$. However, total peripheral vascular resistance gradually increased with the lapse of perfusion time and in these circumstances administration of phenoxybenzamine was effective in reducing it. But in seven cases in this group where an effective cardiac output could not be achieved after repair of the cardiac anomalies, temporary assisted circulation with the administration of dopamine was instituted. The total peripheral vascular resistance in these patients during administration of dopamine at a constant rate $(10$ to $30 \mu \mathrm{g} / \mathrm{kg}$ per min) did not increase compared with the patients using phenoxybenzamine only, and they could come off cardiopulmonary bypass in a stable haemodynamic condition (Table 3).

Fig. 1 shows the course of a girl of 4 years and 5 months weighing $18 \mathrm{~kg}$ who had an endocardial cushion defect and mitral regurgitation. The ostium primum defect was closed with a pericardial patch and the mitral cleft was repaired by two U-stay sutures. As soon as cardiopulmonary bypass was stopped, she lapsed into low cardiac output, with mean arterial pressure $30 \mathrm{mmHg}$, central venous pressure $28 \mathrm{~cm} \mathrm{H}_{2} \mathrm{O}$, and anuria. Low flow-assisted circulation was carried out twice with the combined use of phenoxybenzamine and dopamine. As a result, effective cardiac output and good urinary output were obtained, and she could be taken off assisted circulation.

\section{HYPOTHERMIC GROUP}

The method of deep hypothermia combined with cardiopulmonary bypass was applied in six severe cases whose body weight was about $10 \mathrm{~kg}$. Complete circulatory arrest or extremely low flow perfusion was used in order to make intracardiac operation easier with an oesophageal temperature of 15 to $25^{\circ} \mathrm{C}$.

Table 2 Method of cardiopulmonary bypass

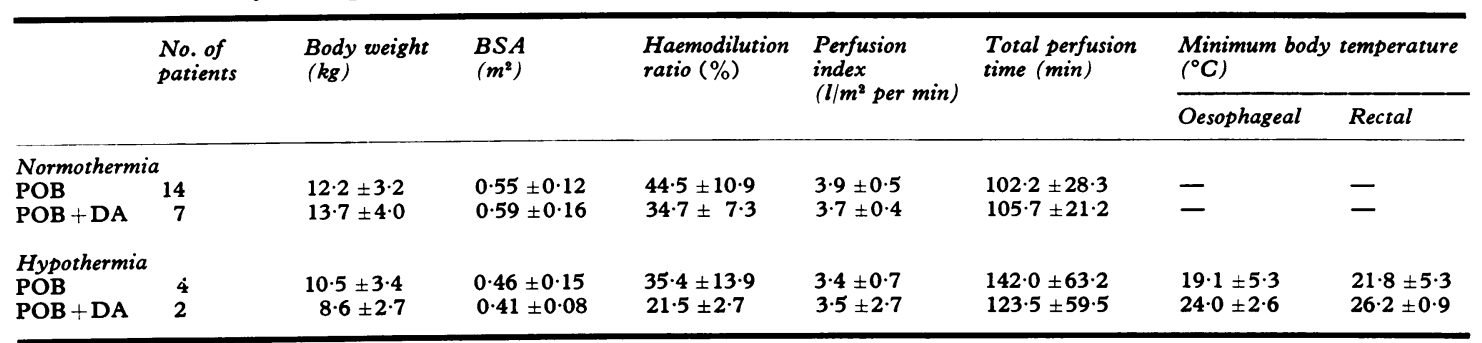

POB, phenoxybenzamine; DA, dopamine; BSA, body surface area. 
Table 3 Serial changes of total peripheral vascular resistance during cardiopulmonary bypass with normothermia

\begin{tabular}{|c|c|c|c|c|c|}
\hline & Cardiopulmonary bypass & & & & \\
\hline & $15 \min$ & $30 \min$ & $60 \min$ & $120 \min$ & 120 to $210 \mathrm{~min}$ \\
\hline POB & $\begin{array}{l}1749 \cdot 00 \pm 477 \cdot 20 \\
(n=14)\end{array}$ & $\begin{array}{l}2248.64 \pm 591.76 \\
(n=14)\end{array}$ & $\begin{array}{l}1782 \cdot 21 \pm 375 \cdot 02 \\
(n=14)^{\star}\end{array}$ & $\begin{array}{l}2432 \cdot 83 \pm 567 \cdot 41 \\
(n=6)\end{array}$ & \\
\hline $\mathbf{P O B}+\mathbf{D A}$ & $\begin{array}{l}1843 \cdot 43 \pm 565 \cdot 08 \\
(n=7)\end{array}$ & $\begin{array}{l}2180 \cdot 14 \pm 684 \cdot 51 \\
(n=7)\end{array}$ & $\begin{array}{l}1696 \cdot 51 \pm 906 \cdot 82 \\
(\mathrm{n}=7)^{\star}\end{array}$ & $\begin{array}{l}2141 \cdot 25 \pm 720 \cdot 59 \\
(n=7) \dagger\end{array}$ & $\begin{array}{l}2144 \cdot 57 \pm 503 \cdot 11 \\
(n=4)\end{array}$ \\
\hline
\end{tabular}

POB, phenoxybenzamine; DA, dopamine.

* After drip infusion of 0.5 to $1.0 \mathrm{mg} / \mathrm{kg}$ phenoxybenzamine.

† During drip infusion of 10 to $30 \mu \mathrm{g} / \mathrm{kg}$ per min dopamine after additional infusion of 0.5 to $1.0 \mathrm{mg} / \mathrm{kg} \mathrm{phenoxybenzamine}$.

Total peripheral vascular resistance increased gradually in proportion to the decrease in blood pressure and body temperature, to about 200 or 300 per cent of normal at 30 minutes of bypass. This returned to about 2000 dynes $\mathrm{s} \mathrm{cm}^{-5}$ at the time of withdrawal from cardiopulmonary bypass by rewarming and administering phenoxybenzamine. In two patients in this group, however, cardiogenic shock with high total pulmonary vascular resistance and oliguria occurred immediately after cardiopulmonary bypass was stopped, and assisted circulation was carried out with a drip infusion of dopamine at a constant rate $(30 \mu \mathrm{g} / \mathrm{kg}$ per $\mathrm{min})$ after the additional administration of phenoxybenzamine $(0.5$ to $1.0 \mathrm{mg} / \mathrm{kg})$. Assisted circulation for a short time produced sufficient arterial pressure and urinary output, with lowering of total peripheral vascular resistance, for these patients to come off cardiopulmonary bypass (Table 4).

Fig. 2 shows the course of a boy of 19 months (6.7 $\mathrm{kg}$ in body weight) with ventricular septal defect, persistent ductus arteriosus, severe pulmon- ary hypertension, and left superior vena cava. The ductus arteriosus was closed by suture ligation under total circulatory arrest combined with deep hypothermia at an oesophageal temperature of $19^{\circ} \mathrm{C}$, and the ventricular septal defect was closed by U-stay suture with a Teflon patch. Phenoxybenzamine was used in a dosage of $0.5 \mathrm{mg} / \mathrm{kg}$ at the time of bypass rewarming. As the arteial pressurer decreased gradually and the central venous pressure increased when cardiopulmonary bypass was withdrawn, assisted circulation with the combined use of phenoxybenzamine and dopamine was required for 31 minutes in order to prevent low cardiac output syndrome.

\section{Discussion}

During cardiopulmonary bypass a patient is considered to be in a state of pre-shock with a moderate increase in systemic vascular resistance. To combat this, many kinds of vasodilators are used during cardiopulmonary bypass and catecholamines are given frequently after bypass. Among

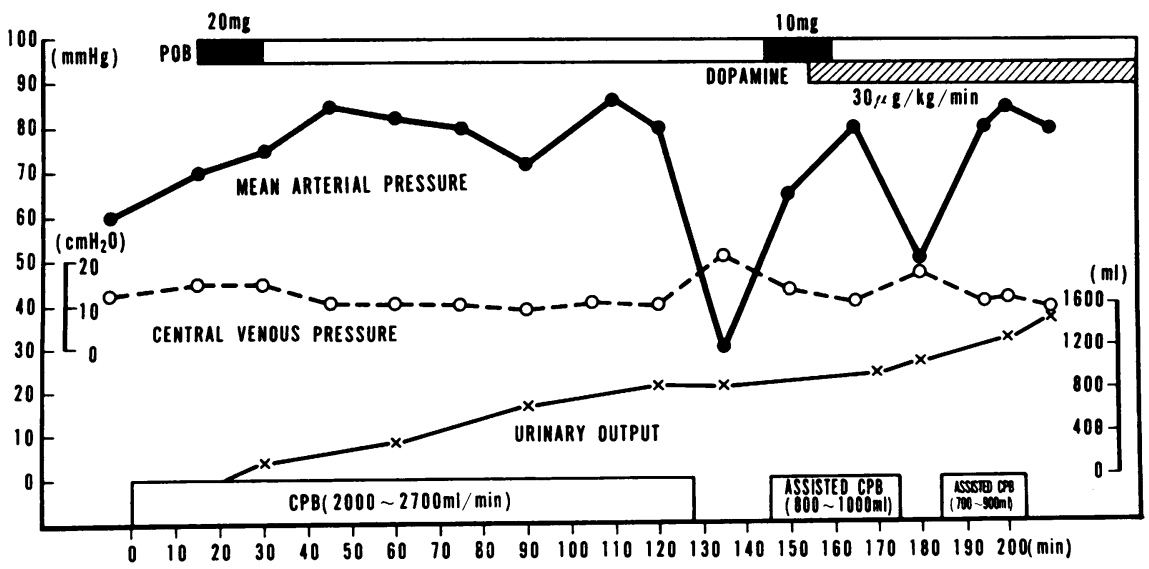

Fig. 1 Haemodynamic changes during study period of patient $H N$. 
Table 4 Serial changes of total peripheral vascular resistance during cardiopulmonary bypass with hypothermia

\begin{tabular}{|c|c|c|c|c|c|}
\hline & Cardiopulmonary bypass & & & & \\
\hline & $15 \min$ & $30 \min$ & 45 to $60 \mathrm{~min}$ & 60 to $120 \mathrm{~min}$ & 120 to $210 \mathrm{~min}$ \\
\hline POB & $\begin{array}{l}2718 \cdot 25 \pm 626 \cdot 32 \\
(n=4)\end{array}$ & $\begin{array}{l}3110 \cdot 75 \pm 876 \cdot 19 \\
(n=4)\end{array}$ & $\begin{array}{l}2113 \cdot 75 \pm 677 \cdot 25 \\
(n=4)^{\star}\end{array}$ & $\begin{array}{l}2307 \cdot 33 \pm 693.02 \\
(n=3)\end{array}$ & \\
\hline POB + DA & $\begin{array}{l}3408 \cdot 50 \pm 350 \cdot 02 \\
(n=2)\end{array}$ & $\begin{array}{l}4073 \cdot 50 \pm 939 \cdot 74 \\
(n=2)\end{array}$ & $\begin{array}{l}4074 \cdot 35 \pm 939 \cdot 67 \\
(n=2)^{\star}\end{array}$ & $\begin{array}{l}2793.50 \pm 770 \cdot 04 \\
(n=2) \dagger\end{array}$ & $\begin{array}{l}2325.50 \pm 1276.33 \\
(n=2) \ddagger\end{array}$ \\
\hline
\end{tabular}

POB, phenoxybenzamine; DA, dopamine.

* After drip infusion of 0.5 to $1.0 \mathrm{mg} / \mathrm{kg}$ phenoxybenzamine.

+ After additional infusion of $1.0 \mathrm{mg} / \mathrm{kg}$ phenoxybenzamine.

¥ During drip infusion of $30 \mu \mathrm{g} / \mathrm{kg}$ per min dopamine.

these drugs, it may be appropriate to use phenoxybenzamine or isoprenaline and dopamine.

Isoprenaline produces cardiac stimulation and mesenteric and peripheral vasodilatation by its action on the beta-adrenergic receptors. Currently, it occupies a position of prominence in the treatment of shock syndrome unresponsive to volume expansion, regardless of aetiology..$^{7-9}$ On the other hand, phenoxybenzamine is known to increase the cardiac output, stroke volume, ${ }^{10}$ and renal blood flow 4 when given intravenously. Alpha-adrenergic receptor blocking drugs such as phenoxybenzamine induce cardiac stimulation mostly because the fall in systemic blood pressure accompanying systemic vasodilatation initiates reflex tachycardia. ${ }^{5}$ Because isoprenaline increases heart rate and causes arrhythmia much more often than does phenoxybenzamine, ${ }^{11} 12$ we combined phenoxybenzamine

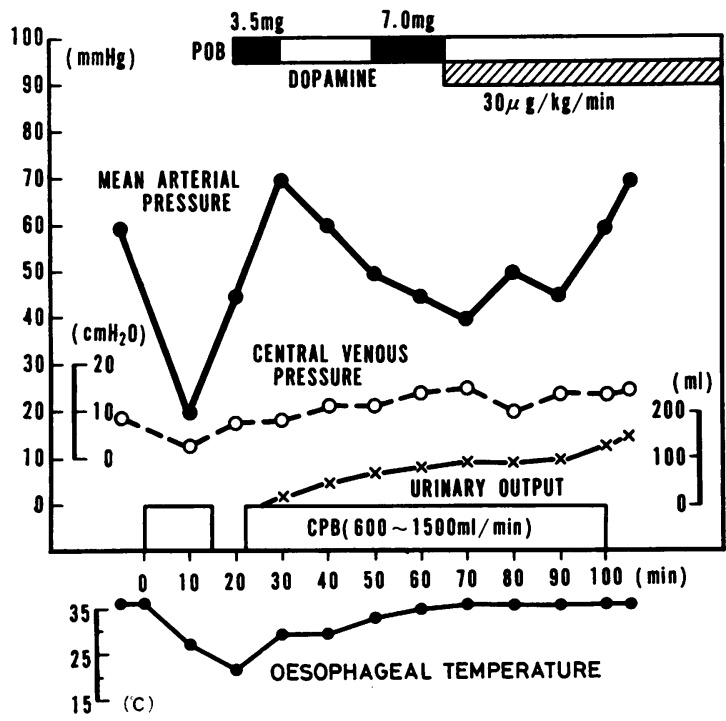

Fig. 2 Haemodynamic changes during study period of patient $K O$. with dopamine in patients in the low cardiac output state at the time of withdrawal of cardiopulmonary bypass.

Many experimental reports have indicated that low doses of dopamine decrease resistance in the renal and mesenteric vascular beds, ${ }^{13-15}$ but not in the limb circulation, ${ }^{2}{ }^{13}$ and that higher doses cause predominant vasoconstriction in both visceral and limb vascular beds. ${ }^{213}$ In addition, many clinical studies indicated that, in adults, low doses (2 to $5 \mu \mathrm{g} / \mathrm{kg}$ per min) caused increased renal blood flow with little effect on heart rate, blood pressure, or myocardial contractility; moderate doses ( 5 to $15 \mu \mathrm{g} / \mathrm{kg}$ per $\mathrm{min}$ ) caused increased renal blood flow, heart rate, cardiac contractility, and cardiac output; and high doses (more than $20 \mu \mathrm{g} / \mathrm{kg}$ per min) produced a renal blood flow which might be reduced. ${ }^{12} 16$ In infants and children, dopamine is a safe drug when used in moderate doses and is effective in increasing blood pressure and urine production with little change in heart rate and central venous pressure. ${ }^{17}$ This unique mechanism responsible for the direct vasodilator effect is believed to be specific to the mesenteric and renal bed. ${ }^{2} 1318$ Furthermore, dopamine increases coronary artery blood flow but with relatively less increase in myocardial oxygen consumption and, therefore, increases myocardial efficiency. ${ }^{13} 19$ The dose of dopamine $(30 \mu \mathrm{g} / \mathrm{kg}$ per min) used in this series is high by the above criteria. But as the circulatory blood volume of the patient increased about twofold during cardiopulmonary bypass in which whole blood and diluent $(800$ to $1500 \mathrm{ml}$ ) were primed into oxygenator and extracorporeal circuit, the actual dose of dopamine was considered to be moderate (about $15 \mu \mathrm{g} / \mathrm{kg}$ per $\mathrm{min}$ ). The combined use of phenoxybenzamine and dopamine provided a stable haemodynamic condition without a high total peripheral vascular resistance and stimulated the removal of diluent by good urinary output.

This method is useful in the treatment of the low cardiac output syndrome when coming off cardiopulmonary bypass. 


\section{References}

${ }^{1} \mathrm{McDonald}$ RH Jr, Goldberg LI. Analysis of cardiovascular effects of dopamine in dog. 7 Pharmacol Exp Ther 1963; 140: 60-6.

${ }^{2}$ McNay JL, McDonald RH Jr, Goldberg LI. Direct renal vasodilation produced by dopamine in the dog. Circ Res 1965; 16: 510-7.

${ }^{3}$ Eble JN. A proposed mechanism of the depressor effect of dopamine in the anesthetized dog. $\mathcal{F}$ Pharmacol Exp Ther 1964; 145: 64-70.

${ }^{4}$ Murphy GP, Gagnon JA, Ewald RA. Renal and systemic hemodynamic effects of Dibenzyline in normotension and hemorrhagic hypotension. Surgery 1965; 57: 856-67.

${ }^{5}$ Aviado DM. Pharmacologic approach to the treatment of shock. Ann Intern Med 1965; 62: 1050-9.

${ }^{6}$ Kawamura M, Miyata Y, Kobayashi A, et al. Hemodilution in practice of cardiopulmonary bypass for infant's open heart surgery. (In Japanese with English summary.) Nippon Kyobu Geka Gakkai Zasshi 1978; 26: $155-62$.

${ }^{7}$ Maclean LD, Duff JH, Scott HM, Peretz DI. Treatment of shock in man based on hemodynamic diagnosis. Surg Gynecol Obstet 1965; 120: 1-16.

${ }^{8}$ Eichna LW. Treatment of cardiogenic shock. III The use of isoproterenol in cardiogenic shock. Am Heart $\mathcal{F}$ 1967; 74: 848-52.

${ }^{\circ}$ Carey JS, Brown RS, Mork PA, Monson DO, Yao ST, Shoemaker WC. Cardiovascular function in shock; responses to volume loading and isoproterenol infusion. Circulation 1967; 35: 327-38.

${ }^{10}$ Block JH, Pierce $\mathrm{CH}$, Lillehei RC. Augmentation of myocardial function with phenoxybenzamine in dogs with cardiogenic shock (abstract). Fed Proc 1965; 24: 529.

${ }^{11}$ Goldberg LI, Talley RC, McNay JL. The potential role of dopamine in the treatment of shock. Prog Cardiovasc Dis 1969; 12: 40-51.

${ }^{12}$ Holloway EL, Stinson EB, Derby GC, Harrison DC. Action of drugs in patients early after cardiac surgery. I. Comparison of isoproterenol and dopamine. $A m \mathcal{F}$ Cardiol 1975; 35: 656-9.

${ }^{13}$ Goldberg LI. Cardiovascular and renal actions of dopamine: potential clinical applications. Pharmacol Rev 1972; 24: 1-29.

${ }^{14}$ Ross G, Brown AW. Cardiovascular effects of dopamine in the anesthetized cat. Am $\mathcal{f}$ Physiol 1967; 212: 823-8.

${ }^{15}$ Yeh BK, McNay JL, Goldberg LI. Attenuation of dopamine renal and mesenteric vasodilation by haloperidol: evidence for a specific dopamine receptor. f Pharmacol Exp Ther 1969; 168: 303-9.

${ }^{16}$ Goldberg LI. Dopamine: clinical uses of an endogenous catecholamine. N Engl f Med 1974; 291 : 707-10.

${ }^{17}$ Driscoll DJ, Gillette PC, McNamara DG. The use of dopamine in children. $\mathcal{F}$ Pediatr 1978; 92: 309-14.

${ }^{18} \mathrm{McNay} \mathrm{JI}$, Goldberg LI. Comparison of the effects of dopamine, isoproterenol, norepinephrine and bradykinin on canine renal and femoral blood flow. f Pharmacol Exp Ther 1966; 151: 23-31.

${ }^{19}$ Crexells C, Bourassa MG, Biron P. Effects of dopamine on myocardial metabolism in patients with ischemic heart disease. Cardiovasc Res 1973; 7: 438-45.

Requests for reprints to Dr Mitsuo Kawamura, 7-7 Uchida Higashi-machi, Inuyama-shi, Aichi-ken 484, Japan. 